\title{
CARACTERIZAÇÃO SOROLÓGICA E MOLECULAR DE ROTAVIRUS SUÍNO NO PARANÁ - BRASIL S.S. KROEFF ${ }^{1}$; V. MUNFORD ${ }^{3}$; M.L. RÁCZ ${ }^{3}$; Y. HAYASHI ${ }^{2}$ \\ ${ }^{1}$ Mestranda do Curso de Pós-Graduação em Ciências Veterinárias, Universidade Federal do Paraná. \\ ${ }^{2}$ Professor Titular do Departamento de Patologia Básica, Universidade Federal do Paraná. \\ ${ }^{3}$ Departamento de Microbiologia, Instituto de Ciências Biomédicas, Universidade de São Paulo.
}

O Brasil possui, atualmente, um dos maiores rebanhos de suínos do mundo, estando entre os sete detentores da produção mundial, com um plantel estimado em 36,5 milhões de cabeças. A região Sul, incluindo os Estados do Rio Grande do Sul, Santa Catarina e Paraná, onde estão localizados os maiores núcleos de criação de suínos, é responsável por mais de $70 \%$ das exportações brasileiras de carne suína. Em todos os países onde a suinocultura é explorada de forma intensiva, os rotavírus representam uma das maiores causas de diarréias infecciosas endêmicas, em várias espécies animais, com alta incidência em suínos e bovinos recém nascidos e desmamados. As diarréias neonatais pré e pós-desmama causam elevadas perdas econômicas, em função da mortalidade de suínos e do decréscimo da taxa de peso vivo e da conversão alimentar. Os rotavírus pertencem à família Reoviridae e ao gênero Rotavirus e possuem tripla camada protéica que envolve o material genético, constituído por 11 segmentos distintos de RNA fita dupla (dsRNA), sendo que cada segmento do dsRNA codifica pelo menos uma proteína viral. A caracterização sorológica dos rotavírus está baseada nas seguintes proteínas: a VP6, proteína do capsídeo interno responsável pela caracterização de grupo e subgrupo; a VP7 e a VP4, localizadas no capsídeo externo e responsáveis pela caracterização de sorotipos e genotipos G e P, respectivamente. Foram colhidas 117 amostras de fezes de leitões nas fases de maternidade e creche em 21 granjas de produção de suínos, das regiões de Toledo, Dois Vizinhos, Marechal Cândido Rondon e Castro, todas do Estado do Paraná, que apresentavam quadros freqüentes de gastroenterite aguda. Todas as amostras foram submetidas a um ensaio imunoenzimático (EIARA-FIOCRUZ) para a identificação de rotavírus do grupo A, das quais, $40(34,19 \%)$ foram positivas. As amostras positivas foram testadas para a caracterização de subgrupo através de um ensaio imunoenzimático com anticorpos monoclonais (Mab-ELISA). Nove amostras foram caracterizadas como grupo A e subgrupo II e 31 fizeram parte do grupo A e subgrupo nãoI-nãoII. Para a caracterização de genotipos $G$ e $P$ utilizou-se a técnica de transcrição reversa, seguida da Reação em Cadeia de Polimerase (RT-PCR) com primers específicos para rotavírus suínos, bovinos e humanos. Das 40 amostras positivas para rotavírus, 18 puderam ser caracterizadas como genotipo G e 30 como genotipo P. Foram encontrados os genotipos G3, G4, G5, G9 e G10 e uma amostra com os genotipos G4 e G9 ocorrendo simultaneamente. Quanto ao genotipo P foram observadas amostras $\mathrm{P}[6], \mathrm{P}[7]$ e misturas de $\mathrm{P}[6]$ e $\mathrm{P}[7]$ ocorrendo num mesmo animal. Este estudo mostrou uma diversidade de genotipos ocorrendo ao mesmo tempo em uma região e em uma mesma granja, inclusive o genotipo G9, que até o momento não havia sido descrito em amostras de suínos, somente em humanos. 